COGNITIVE STUDIES | ÉTUDES COGNITIVES, 12

SOW Publishing House, Warsaw 2012

ROMAN ROSZKO

Institute of Slavic Studies, Polish Academy of Sciences, Warsaw, Poland

roman.roszko@ispan.waw.pl

\title{
LEXICAL EXPONENTS OF HYPOTHETICAL MODALITY IN POLISH AND LITHUANIAN
}

\begin{abstract}
The article focuses on the lexical exponents of hypothetical modality in Polish and Lithuanian. The purpose for comparing and contrasting the lexical exponents of hypothetical modality is not only to identify all the lexemes in both languages but also find the answer to the following question: whether the morphological exponents of hypothetical modality (so-called modus relativus) familiar to the Lithuanian language have/had an influence on limiting the number of the lexical exponents and the frequency of using these exponents in the Lithuanian language (in comparison with Polish).

To analyse both the languages there is used the method of theoretical contrastive studies, which the most important features are: (1) orienting the studies from the content grounds to the formal grounds, (2) using a semantic interlanguage as tertium comparationis. First of all, the content of hypothetical modality and its definition and paraphrase is given here. Next, the gradational character of this category is discussed. There are distinguished six groups of lexemes expressing the corresponding degrees of hypothetical modality — from a shadow of uncertainty (minimal degree of probability) to an almost complete certainty (maximum degree of probability). The experimental Polish-Lithuanian corpus is widely applied in the studies.

Keywords: Polish and Lithuanian languages, hypothetical modality, contrastive studies, corpora.
\end{abstract}

\section{Introduction. Theoretical contrastive studies}

The question of the lexical exponents of hypothetical modality in comparing and contrasting Polish and Lithuanian presented here has been prepared on the basis on the guidelines for theoretical contrastive studies (hereinafter referred to as TCS). To begin with, it should be clearly emphasized that TCS reject a direct comparison and contrast between natural languages. Each of the analyzed languages is contrasted with an interlanguage, being tertium comparationis in the studies conducted. The interlanguage is nothing else but a relatively simple, accurate and coherent definition of a concept, here - a semantic category of hypothetical modality. 
The interlanguage concept was introduced by the Semantics Department of the Institute of Slavic Studies of the Polish Academy of Sciences (at that time known under the name of the Laboratory of South Slavonic Languages), see (Project 1984, Koseska, Gargov 1990). The Polish term is based on the English original interlanguage, brought into the literature by Selinker (1972). On the other hand, the interlanguage concept is a development of the idea of the studies noticed by Selinker (1972). However, it is obvious that a direct comparison and contrast between languages leads to mechanical retrieving for the chosen forms of the original language their equivalents (translations) in the target language. Therefore, in such contrastive studies - here symbolically called traditional studies - the original language most often means one's native tongue (language A), whereas the target language - means a foreign language (language B). It is easy to notice that depending on which of the languages is taken as original and which as target, different results are obtained $(\mathrm{A} \rightarrow \mathrm{B} \neq \mathrm{B} \rightarrow \mathrm{A})$. Even the sum of results of the both differently directed comparisons does not provide a complete description, just the opposite it becomes a set of incoherently inconsistent uses.

The TCS model adopted here postulates the following sequence of the studies. First, an interlanguage is defined for a problem being analysed. This stage of research comprises not only a definition of the interlanguage concept, but also a description of distinctive subcategories. Next, each of the languages put in comparison (here: Polish and Lithuanian) is directly contrasted with the interlanguage. The results of the separate, independent contrast between the interlanguage and the Polish language, as well as the interlanguage and the Lithuanian language are being given concurrently. Thanks to this method, the outcome is a reliable result of the Polish-Lithuanian comparison and contrast, which is not burdened with mistakes resulting from the projection of the structure of one language (original language A) onto the elements of usage in the other language (target language B). It is worthwhile to emphasize the fact that TCS make it possible to analyse the exponents of meanings that have a different degree of formalization in the languages being contrasted. The semantic category of hypothetical modality described here is a good example of the fact. The Lithuanian language created lexical, morphological and syntactic means to express hypothetical meanings, whereas the Polish language - only lexical and syntactic. The lack of morphological exponents of hypothetical modality in Polish can give rise to a larger number of lexical exponents in Polish (in comparison with Lithuanian). And is it so in fact? I am going to answer it in this article.

\section{Definition of hypothetical meanings}

The definition of hypothetical meanings adopted here comes from the studies conducted by Vjara Maldjieva (Maldžieva 2003). Hypothetical modality is one the categories characteristic of the natural language and expresses the subjective attitude of a speaker/sender to the states and actions presented by himself ${ }^{1}$. Hypothetical modality is, according to the TCS guidelines, interpreted as a sentence category.

\footnotetext{
${ }^{1}$ The concepts of a state and an action refer to the implementation of the Petri system to describe linguistic phenomena (Mazurkiewicz 2008).
} 
Therefore, an analysis of the category exponents should be conducted on the following levels: lexical, morphological and syntactic ${ }^{2}$. Maldjieva defines the category of hypothetical modality as one of the linguistic categories of a simple content. The presence of a possibility functor in the semantic structure of a hypothetical sentence is a distinctive feature of the category ${ }^{3}$. Maldjieva adopts comparability of hypothetical meanings. Thus, on a line described by a probability parameter she interposes intermediate values of probability between the extreme values of true (1) and false (2). She rules out the median value of $1 / 2$ as a possible value of hypothetical meaning. In an article by Danuta Roszko, including references to the studies conducted by Maldjieva, the issue of comparability of hypothetical meanings is presented in a different way. The value of $1 / 2$ is recognised as neutral, i.e. the probability value $P(x)$ of a sentence and its negation $\neg P(x)$ have the same value. In other words, the value of $1 / 2$ is a degree of probability with which a sender marks the contents described as uncertain, without an additional proposal/suggestion of interpretation being more or less close to one of the extreme values of true or false. This way of interpreting the median value $(1 / 2)$ on the probability scale results from the author's studies on the exponents of possibility modality in the Lithuanian local dialect of Punsk, see (D. Roszko, 2006) and (D. Roszko, in this volume). Her research proves that using the dialectal perfectum forms is equivalent to expressing the probability value of $1 / 2$. The classification possibility of a probability degree appears along with the use of the lexical or syntactic dialectal exponents of hypothetical modality.

\section{Paraphrase of hypothetical meanings}

In the theoretical contrastive studies, two presentation ways of meanings are adopted. One of them is a formalized record, and the other is a paraphrase. In this work, an explication based on a paraphrase is used to illustrate hypothetical meanings.

An exemplary hypothetical sentence paraphrase (in italics) ${ }^{4}$

[1] — Na proroka! — zawołał zmieszany i przelękły — chyba lew bieży ku nam i jest juz tuż!

Eng: For heaven's sake! — he cried out confused and frightened - a lion is probably running towards us and is just close onto us!

[Henryk Sienkiewicz In Desert and Wilderness]

'The speaker supposes that a lion is running towards them and is very close'.

\section{Exponents of hypothetical modality in Polish and Lithuanian}

The semantic category exponents of hypothetical nature include the following forms: lexical, morphological and syntactic. All the forms are characteristic of the Lithuanian language. The Polish language in comparison with Lithuanian is deprived of morphological exponents of hypothetical meanings.

\footnotetext{
${ }^{2}$ In this article - according to the TCS guidelines mentioned in Section 1 - the description is narrowed to lexical exponents of hypothetical modality.

${ }^{3}$ In the modal sentence structures a possibility or necessity functor can appear. The sentences without the functor are non-modal sentences.

${ }^{4}$ All the examples presented here derive from the parallel Polish-Lithuanian corpus.
} 
On account of the fact that only lexical exponents of hypothetical modality are the object of the studies, below are presented some selected examples of morphological exponents (for the Lithuanian language) and syntactic exponents (for both languages).

[2] Bene nuo žmonos jis atsiskyręs esąs. (Ambrazas (Ed.) 1997: 264)

'The speaker supposes that $\mathrm{X}$ does not live together with his wife (they are in separation).'

[3] Myślę, że Giese dałby sobie zapewne uciąć rękę, żeby się dowiedzieć choć tego, czemu tak się dzieje.

Manau, jog Gezè būtų leidęs nukirsti sau ranką, kad galètu sužinoti, kodèl taip dedasi.

'The speaker supposes that Giese would swear blind to learn at least the fact why it is happening that way.'

\section{Lexical exponents of hypothetical modality in Polish and Lithuanian}

In both analysed languages, the lexical exponents of hypothetical modality create an extensive group of lexemes. An exceptional feature of the lexical exponents of hypothetical modality is the fact that they can expose different levels of probability of the contents expressed by a speaker. This very feature is used to classify Polish and Lithuanian lexemes. The idea of the division of lexical exponents into the groups of a different value of probability degree is taken from (Maldžieva 2003). Below are presented the lexemes classified according to their values on the probability axis.

\subsection{First group}

This group of exponents of a slight degree of expressing hypothetical meanings comprises compound phrases: the Polish może $i$ and the Lithuanian gal ir:

[4] Może $i$ był pijany, ale wiedział, co mówi.

Gal jis ir buvo girtas, bet žinojo, ką sakąs.

[5] Tak więc fizycy, a nie biologowie, wysunęli paradoksalne sformułowanie „maszyna plazmatyczna" rozumiejąc przez to twór, w naszym znaczeniu może $i$ nie ożywiony, ale zdolny do podejmowania celowych działań na skale dodajmy od razu - astronomiczną.

Taigi fizikai, o ne biologai pasiūlè paradoksalią formuluotę „plazminè mašina”, turèdami galvoj tvarini, mūsu supratimu gal ir be gyvybès, tačiau gebanti tikslingai veikti, iškart pridurkim, astronominiu mastu.

A distinctive feature of Polish and Lithuanian exponents of this group is the presence of the Polish $i$ and of its Lithuanian literal equivalent $i r$. The elements mentioned above influence the weakening of a probability degree which accompanies the exponents used individually: the Polish może and the Lithuanian gal. 
Table 1. Polish and Lithuanian exponents of group 1.

\begin{tabular}{|l|l|}
\hline \multicolumn{1}{|c|}{ Polish } & \multicolumn{1}{c|}{ Lithuanian } \\
\hline może i & gal ir \\
\hline
\end{tabular}

\subsection{Second group}

This group is a variant of the first group. The exponents distinguished in 5.1. are extended to comprise the prepositional Polish element $a$ and its literal Lithuanian equivalent $o$, see the compound Polish phrase a mozie $i$ and the compound Lithuanian phrase o gal ir. An analysis of the parallel Polish-Lithuanian corpus reveals another Polish-Lithuanian compatibility może zreszta $i$ and o gal ir, see:

[6] O tym nic nie mówił. Może zreszta mówił, ale zbudziłeś się i wyłączyłam taśmę.

To jis nesakè. O gal ir sakè, bet tu nubudai, ir aš išjungiau magnetofoną.

[7] — Słuchaj, a może $i$ jest najpiękniejsza, lecz dla mnie zbyt wysoka.

- O gal ir ji pati gražiausia, bet man per aukšta.

Table 2. Polish and Lithuanian exponents of group 2.

\begin{tabular}{|l|l|}
\hline \multicolumn{1}{|c|}{ Polish } & \multicolumn{1}{c|}{ Lithuanian } \\
\hline $\begin{array}{l}\text { a może i } \\
\text { może zresztac }\end{array}$ & o gal ir \\
\hline
\end{tabular}

\subsection{Third group}

The probability classification is also reflected in a formal plan. This group of exponents of hypothetical modality is a modification of the formal level of the previous group. In this case, the added element of the second group remains, whereas the characteristic element of the first groups is omitted, see the Polish a może and the Lithuanian o gal:

[8] Oprócz tej książki była jeszcze inna książka o Krzysiu i ten, kto ją czytał, przypomni sobie, że Krzyś miał kiedyś swojego łabędzia (a może to łabędź miał swojego Krzysia? - nie wiem na pewno, jak tam było), a ponieważ łabędź był pokryty białym puchem, Krzyś nazwał go Puchatkiem.

Be šios knygelès, buvo dar viena knyga apie Jonuką, ir kas ją skaitè, tikriausiai atsimena, kad Jonukas kadaise turèjo gulbiną ( o gal gulbinas turèjo Jonuką — tiksliai negaliu pasakyti), kurị vadino Pūkuotuku.

[9] Może twoje zjawienie się miało być torturą, może przysługą, a może tylko mikroskopowym badaniem.

Gal tavo pasirodymas turèjo būti kankynè, gal paslauga, o gal tik mikroskopinis bandymas. 
Table 3. Polish and Lithuanian exponents of group 3.

\begin{tabular}{|l|l|}
\hline \multicolumn{1}{|c|}{ Polish } & \multicolumn{1}{c|}{ Lithuanian } \\
\hline a może & o gal \\
\hline
\end{tabular}

\subsection{Fourth group}

This group of exponents is largely represented. Both Polish and Lithuanian developed a lot of parallel exponents to express a stronger probability, see the Polish chyba, może jednak, może rzeczywiście, może naprawde and the Lithuanian nebent, gal, gal tikrai, gal vistiek, matyt:

[10] Domyślacie się chyba, co miałem zamiar zrobić — wyjaśnił Puchatek fikając koziołka i zlatując na łeb, na szyję na inną gałąź o trzy łokcie niżej.

- Matyt, supratote, ką norèjau padaryti, — paaiškino Pūkuotukas virsdamas kūliais ir atsitrenkdamas dar ị vieną šaką, augančią devyniais metrais žemiau.

[11] — Jeżeli będę słyszała twój głos, to chyba dam sobie radę.

- Jei girdèsiu tavo balsą, tai gal ištversiu.

[12] Więc może zrobię najlepiej, jeśli skończę pisanie Przedmowy i zacznę pisać samą książkę.

Todèl gal bus geriau, jei baigsiu Ǐžangą ir pradèsiu pačią knygą.

[13] Kris, proszę, powiedz mi wszystko, co wiesz, może jednak uda się coś zrobić? Krisai, prašau tave, pasakyk man viską, ką žinai, gal vis tiek pasisektų ką nors padaryti?

Table 4. Polish and Lithuanian exponents of group 4.

\begin{tabular}{|l|l|}
\hline \multicolumn{1}{|c|}{ Polish } & \multicolumn{1}{c|}{ Lithuanian } \\
\hline chyba & gal \\
może jednak & nebent \\
może rzeczywiście & gal tikrai \\
może naprawdę & gal vistiek \\
& matyt \\
\hline
\end{tabular}

\subsection{Fifth group}

This group of exponents comprises enhanced means to express hypothetical modality. The following exponents are to be found here: the Polish być może, może, wydaje sie, pewnie, zdaje się, tak myśle, moim zdaniem, zapewne, widać and the Lithuanian manyčiau, gal, galbūt, turbūt, rodos, man rodos, man atrodo, atrodo, berods, taip manau, pagal mane, galimas daiktas, pasirodo: 
[14] - Ajaj! Co za nieszczęście! Pewnie biegłeś za szybko.

— Nic nie szkodzi, Puchatku — rzekł Prosiaczek pocieszająco.

- Może innym razem.

— Vai, kokia nelaimè! Turbūt per greitai bègai.

- Nieko tokio, Pūkuotuk,- nuramino ji Paršelis.

- Gal kitą kartą.

[15] Zróbcie coś. Zdaje się, że tracę stabilizację.

Darykite ką nors. Man rodos, aš netenku stabilizacijos.

[16] Żebym ci powiedział, jakie plany knuje przeciw nam x bilionów metamorficznej plazmy? Być może żadnych.

Kad pasakyčiau tau, kokia klastą mums ruošia iks metamorfinės plazmos bilijonai? Galimas daiktas, nieko.

[17] — Nie wiem. Nie jestem fizykiem. Być może, stabilizuje je jakieś pole siłowe.

- Nežinau. Aš ne fizikas. Galimas daiktas, kad juose stabilizuojasi koks jëgu laukas.

An analysis of Polish and Lithuanian exponents of this group also reveals the following analogies, see może — gal, być może — galbūt / gali būti. What intrigues is the Lithuanian form manyčiau which takes first person singular of the conditional of the verb manyti 'to think'. It is also worthwhile to pay attention to the Lithuanian contract form turbūt (turi būti: literally musi być / ma być), and the use, in the function of a hypothetical modality exponent, the Polish form of the undue (predicative) intransitive verb widać. Occasionally, in the experimental Polish-Lithuanian corpus the book form snadz $\tilde{z}^{5}$ is mentioned, e.g.:

[18] Brudny pudel otwiera jedyne oko, jakie mu pozostało, i snadź dostrzegłszy niezwykłe ożywienie swego pana zeskakuje z kufra na podłogę.

[19] Ten głos snadź rzucił na nią czar -

Stanęła urzeczona,

I wtedy spełnił się jej los,

Gdy padła mu w ramiona.

Table 5. Polish and Lithuanian exponents of group 5.

\begin{tabular}{|l|l|}
\hline \multicolumn{1}{|c|}{ Polish } & \multicolumn{1}{c|}{ Lithuanian } \\
\hline być może & galbūt \\
może & gal \\
& turbūt \\
pewnie & man rodos
\end{tabular}

\footnotetext{
${ }^{5}$ Relatively often, the lexeme snadz appears in the works of Stanislav Lem, also is to be found in translations of literary prose, e.g. J.R.R. Tolkien, Lord of the Rings, vol.1, and Team of the Ring, see example [18].
} 


\begin{tabular}{|l|l|} 
zapewne & taip manau \\
tak myślę & pagal mane \\
widać & pasirodo \\
wydaje się & atrodo \\
zdaje się & rodos \\
& berods \\
raczej & man atrodo \\
& galimas daiktas \\
& manyčiau \\
& veikiau \\
\end{tabular}

\subsection{Sixth group}

It is the last of all the groups distinguished. A distinctive feature of this group is the highest degree of probability. Here belong such lexemes as: the Polish najpewniej, najprawdopodobniej, moim zdaniem, jak widać, jak sadze, jak przypuszczam, jak mi sie zdaje ${ }^{6}$, na pewno, niewatpliwie, widocznie, najwidoczniej, bez watpienia, bez watpliwości and the Lithuanian tikriausia, kaip man atrodo ${ }^{7}$, veikiausiai, be abejonès, matyt, man panašiausia, be abejonès, iš tikro, rasi, see:

[20] Dlaczego? I na to pytanie nie znajduję odpowiedzi, najprawdopodobniej dlatego, że mój wybieg był już nazbyt prosty.

Kodèl? Ir ị ši klausimą nerandu atsako. Veikiausiai todèl, kad mano gudrybè buvo pernelyg jau paprasta.

[21] Był to pokój większy od mego, też o panoramicznym oknie, w trzech czwartych zasłoniętym przywiezioną niewatpliwie z Ziemi, nie należącą do ekwipunku Stacji, firanką, w drobne niebieskie i różowe kwiatki.

Kambarys buvo didesnis už manajị, irgi su panoraminiu langu, per tris ketvirtadalius uždengtu smulkiom melsvom ir rausvom gèlytėm išmarginta užuolaida, be abejonès atsivežta iš Žemès, nepriklausančia Stoties turtui.

[22] Sartorius uważa, że skoro „gość” pojawia się zawsze tylko wtedy, kiedy się budzisz, to widocznie on wyciąga z nas receptę produkcyjną podczas snu.

Sartorijus mano, kad jeigu „svečias“ pasirodo tik tada, kai bundi, tai, matyt, okeanas ištraukia iš mūsų gamybinį receptą mums miegant.

The meaning deducted from the use of the above-mentioned Polish and Lithuanian lexical exponents proves the fact that the sender is all but sure about the truth of the facts (states and events) passed by himself. The Polish jak mi sie zdaje and

${ }^{6}$ With an accent falling on the pronominal form $m i$.

${ }^{7}$ Also in the Lithuanian lexeme, an accent falls on the pronominal form man. 
the Lithuanian kaip man atrodo is characterized by emphasizing the pronominal forms $m i$ and man. If there is lack of such enhancement, these exponents can come under the fifth group (5.5.).

Table 6. Polish and Lithuanian exponents of group 6.

\begin{tabular}{|l|l|}
\hline \multicolumn{1}{|c|}{ Polish } & \multicolumn{1}{|c|}{ Lithuanian } \\
\hline najpewniej & tikriausia \\
tikriausiai \\
najprawdopodobniej & veikiausiai \\
moim zdaniem & mano galva \\
jak widać & matyt \\
bez wątpliwości & be abejonès \\
jak sądzę & kaip manau \\
jak przypuszczam & kaip man atrodo \\
jak mi się zdaje & man panašiausia \\
na pewno & iš tikro \\
niewątpliwie & be abejonès \\
widocznie & rasi \\
najwidoczniej & \\
bez wątpienia & \\
\hline
\end{tabular}

6. Relations between the number of exponents of hypothetical modality in a language having morphological exponents (here Lithuanian) and in a language not having morphological exponents (here Polish)

Before conducting the studies, it seemed obvious to me that lack of the morphological form of an exponent of hypothetical meanings in Polish would translate into a higher number of lexical exponents in Polish. The comparison of lexical exponents in Polish and Lithuanian presented above proves the opposite. In Lithuanian, the number of lexical exponents is a little larger. However, it is not a significant predominance, nevertheless, worth noticing. Polish is characterized by a high diversity of lexemes only in the sixth group comprising the lexemes expressing the highest degree of a sender's certainty. Obviously, this conclusion can be useful in the research on the linguistic image of the world.

The frequency of using the corresponding lexical exponents in both languages is a more relevant conclusion. In Polish, part of the lexemes is characterized by a very high frequency of their use (e.g. chyba, wydaje mi sie, prawdopodobnie, pewnie...), and others - a definitely lower frequency. In Lithuanian, the scope of differences in the frequency of using the corresponding exponents is much lower. Moreover, in particular texts (both in translations from English as well as Polish), the diversity 
of the lexical exponents used is higher in Lithuanian texts. It can describe either the language of a translator or reflect the universality typical of the Lithuanian language to use a larger number of lexical exponents. In order to confirm or negate one of the two aforementioned hypotheses, there should be provided a wider analysis of the texts typical of the comparable corpora. Unfortunately, the experimental PolishLithuanian comparable corpus resources, on account of the insufficient number of lexical exponents of hypothetical modality, do not make it possible to conduct such studies. Whereas, the parallel corpora are in this case unreliable.

\section{Conclusions}

Hypothetical modality is considered as a meaning (semantic) category. Therefore, hypothetical meanings can be expressed with the help of exponents belonging to different levels of a language. As far as Polish and Lithuanian are concerned, lexical and syntactic exponents as well as their combinations are characteristic for both the languages. Moreover, Lithuanian developed the morphological exponents of hypothetical meanings - these are forms referred to as modus relativus. The Lithuanian morphological exponents can cooperate with the lexical and syntactic exponents of hypothetical meanings.

The lexical exponents of hypothetical meanings can be classified basing on their probability degree. In both languages compared and contrasted, the comparison of a probability value is clearly noticed both on the semantic and formal level. Therefore, in the interlanguage of a semantic category of hypothetical modality, applied in an analysis of these languages (Polish and Lithuanian), the idea of classification of hypothetical contents has been adopted. In linguistic reality, it corresponds with different degrees of possibility/probability which are ascribed to the meaning given by a sender. It should be emphasized, however, that it is a speaker who is the source of a possibility/probability expressed by himself. Technically, the classification of meanings can be illustrated as an axis on which there are arranged six assumed values, beginning with a low degree of probability (the first group), and ending with a high degree of probability (the sixth group).

In the research on the semantic category of hypothetical modality, there have been applied the experimental parallel Polish-Lithuanian corpus resources. This fact results in the given regular Polish-Lithuanian uses of corresponding lexical exponents being recognised as those of a high probability. All the same, the corpus data prove that the lines between every two neighbouring groups are floating. In practice, it means that - for example - an exponent coming under the fifth group can be used to express a probability degree ascribed to the fourth or third group.

In principle, a significant parallel between the corresponding groups of lexemes in both languages is to be observed. This conclusion concerns both the number of the lexemes and the very structure of the compound lexical expressions (see PL a może $i$ : LT o gal ir, PL bez watpienia : LT be abejonés etc.). It is noticeable that Polish exponents have a slightly higher specialization level, and the exponents according to Grochowski (1986) should be recognized as particles. In the model of morphosyntactic taggers worked out by Adam Przepiórkowski (the project manager) and Marcin Woliński for the IPI PAN corpus needs, the exponents are referred to as the-so-called cublics (Woliński 2004). In the resources of a computer 
dictionary of Lithuanian (LKŽ 2008), it is difficult to find the lexemes discussed in this article, since they do not have their own entry. The Lithuanian lexeme gal is probably their only representative. In the model of morphosyntactic taggers (MA 2010) only the Lithuanian lexeme gal is recognized as a particle. The other forms, both in LKŽ and MA are recognised as a paradigm of the corresponding verbal forms, e.g. the Lithuanian form atrodo is described as third person singular or the plural of the verb atrodyti ${ }^{8}$.

The number of lexical exponents of hypothetical modality is higher in the Lithuanian language. Polish lexemes are characterized by a big frequency scatter of their use. Some of the lexemes are characterized by a very high frequency of their use, others rarely appear in a text. Even in translations from Polish into Lithuanian a big diversity of the lexical exponents of hypothetical modality is to be observed, e.g. the Polish chyba corresponds with the Lithuanian turbüt, nebent, rasi.

\section{References}

Dimitrova L. \& Koseska-Toszewa, V. \& Roszko, D. \& Roszko, R. 2010. Application of Multilingual Corpus in Contrastive Studies (on the example of the BulgarianPolish-Lithuanian Parallel Corpus), Cognitive Studies / Études Cognitives 10 (217239).

Selinker, L. 1972. Interlanguage, Iral 10-

LKŽ 2008. Lietuviu kalbos žodynas, electronic version, first issue (2005), last update (2008): http://www.lkz.lt

MA 2010. Morfologinis anotatorius: http://donelaitis.vdu.lt/main.php?id $=4 \& n r=7 \_1$.

Maldžieva, V. 2003. Modalność: hipotetyczność, irrealność, optatywność i imperatywność, warunkowość, Gramatyka konfrontatywna bułgarsko-polska, volume 6, part 3, SOW. Warszawa.

Projekt 1984: Projekt gramatyki konfrontatywnej bułgarsko-polskiej i serbskochorwackopolskiej [In:] K. Polański (Ed.) Studia polsko-południowosłowianskie, Wrocław.

Roszko, D. 2006. Funkcjonalne odpowiedniki litewskiego perfectum w litewskiej gwarze puńskiej $i$ w języku polskim, Warszawa.

Roszko, D. in this volume. Semantic Contrastive Linguistics Theory and Dialectological Studies.

Roszko, D. \& Roszko, R. 2009. Morphosyntactic Specifications for Polish and Lithuanian. [Description of Morphosyntactic Markers for Polish and Lithuanian Nouns within MULTEXT-East Morphosyntactic Specifications (Version 3.0 May 10th, 2004)] - Representing Semantics in Digital Lexicography Innovative Solutions for Lexical Entry Content in Slavic Lexicography, MONDILEX Fourth Open Workshop Warsaw, Poland, 29 June - 1 July, 2009, SOW Publishing House, Warsaw: 209-213.

Woliński, M. 2004. System znaczników morfosyntaktycznych w korpusie IPI PAN. Polonica XII, PL ISSN 0137-9712, 39-54.

\footnotetext{
${ }^{8}$ See $<$ word $="$ Atrodo" lemma="atrodyti(-do,-dè)" type="vksm., teig., nesngr., tiesiog. n., es. l., vns., 3 asm." /> (MA 2010).
} 